\title{
ACTIVE HOUSE: A CONTEMPORARY HOUSING MODEL FOR FLOOD AFFECTED POPULATION
}

\author{
UDC 72.012:502
}

\section{Tatjana Stratimirović, Milena Kordić, Srđan Marlović}

\author{
University of Belgrade, Faculty of Architecture, Serbia
}

\begin{abstract}
The effectiveness of architectural knowledge in the struggle for a better future can be seen in the attitude that a good design or a good architectural solution, does not belong solely to the privileged ones as an improvement of the basic requirements, rather quite the opposite, that it is created as a response to a need. The goal of physical and emotional wellbeing, combined with a long term strategy for reducing the negative impact of the built environment by converting it into a positive influence upon the natural ecosystem, brings together and advances bioclimatic principles, architectural design and sustainable construction in the contemporary housing model dubbed the Active House. The Active House Workshop was held, as part of a wider student initiative New Housing Models for Flood Affected Population, at the University of Belgrade - Faculty of Architecture. The purpose of the campaign was to provide help to flood affected communities and assistance in efforts for repairing buildings in Serbia, hit by the severe floods of May 2014. Students came up with nine design solutions for small family homes, which incorporate the principles of Active House into existing construction techniques. In an architectural context, when concerning repair work after flooding, the need to consider problems related to contemporary living conditions through the 'active' category is seen in a new understanding of nature which allows the replacement of a passive restoration model, with an active models for designing in interaction with the environment.
\end{abstract}

Key words: Active House, housing model, comfort, architectural design, influence on environment, May floods.

\section{INTRODUCTION: ARCHITECTURE AND CRISIS}

The challenges with which architecture is faced while responding to the needs of vulnerable social groups activate basic mechanisms which renew the spirit of invention. In such situations it becomes evident that a good design or a good architectural solution does not belong only to the privileged ones as an improvement upon basic requirements,

Received May 30, 2015 / Accepted August 19, 2015

Corresponding author: Tatjana Stratimirovic, University of Belgade, Faculty of Architecture,

Department of Architecture, Bulevar Kralja Aleksandra 73/II, Serbia

E-mail: strati@arh.bg.ac.rs 
rather quite the opposite, that it is created as a response to a need. Over the last few decades many organizations, movements and initiatives were launched with the idea that everyone should have a right to good quality architecture, and efforts were made to demonstrate the power of expert architectural knowledge in the struggle for a better future for vulnerable individuals and social groups.

The social role of architecture in this context is seen through the relationship between architecture and local communities, which requires wider participation by social groups in the design process, as much as the development of strictly expert, experimental design procedures as a response to the specific needs of a community. This encourages progress within architecture as an academic discipline by exploring new design and construction tools and techniques, as well as by extending the boundaries of architecture concerning other disciplines in an effort to offer new, educational models.

The modesty and authenticity of motives in resolving issues of underprivileged social groups, makes it possible for architects to renew their own creative potential. In critical situations, revising the tenets of their discipline by architects, and the renewal of the pursuit (and right to) a better life on the part of occupants, architecture and life, man and space, are brought closer together.

During the previous few decades, responses within architectural practice to challenges posed by today's problems such as climate change, diminishing natural resources and the destabilization of natural processes, were primarily led by technological imperatives and market demand (Brundtland Report, 1987.) Current humanitarian crises (social and natural) do not allow the resolution of these problems through high tech solutions. In this context, needs arise for a new understanding of interaction with nature. By renewing man's relation with nature contemporary models of day-to-day routine alterations and suitable spatial frameworks are being sought.

In this manner architecture of necessity explores possibilities of its reconceptualization in detaching from tectonic, and becoming closer to climatic and cultural issues, in transition from visible to invisible spatial elements. This ensures a conceptual level of envisaging environmental issues, contrary from grounding architectural production on a strictly technical or technological level.

In the search for an authentic relationship between architecture with the environment, with as little as possible technical or technological mediators, there emerges the interest in the principles of the Active House. These principles are mainly related to investigating the positive influence of buildings on their environment. With the minimization of the harmful influence of usage of residential buildings, on air, water and soil quality of the surrounding environment, as a starting point, we reach the stage when it becomes necessary to consider issues such as energy consumption and the reduction of harmful emissions from buildings. Environmental concerns are demonstrated through attention to the lifespan of the building. All elements of the building must be considered through this prism, which makes it necessary to form a new housing model through inventive approaches which lead to the idea of the Active House.

\section{THE ACTIVE House CONCEPT}

The family home is the basic unit of any built environment, and precisely this fact gives it its active potential. The importance of the intimate connection between the spatial solution of a house with physical comfort and a healthy outlook on one's life is affirmed 
by the fact that we spend $90 \%$ of our personal time indoors, and that $40 \%$ of the energy we use is consumed by the house.

The goal of physical and emotional wellbeing, combined with the long term goals of not only reducing the harmful influence of the built environment, but converting this influence into a positive one for the natural environment, is formulated through a few very simple, well known design problems which, it is always well worth thinking about anew: (1) comfort: insolation and views, indoor air quality, natural temperature control in the house; (2) energy saving: an energy efficient home, minimal consumption, integration of various supplemental energy sources; (3) positive influence on the environment: natural and recycled construction materials, low $\mathrm{CO}_{2}$ emissions while living, minimal consumption of fresh water. The specified 9 active principles establish the structure for the development of the elements of the standard for modern housing models, upon which the concept of Active House is based (The Active House Alliance, 2011).

Since it is universally acknowledged, the Active House concept with its principles strives towards universality in its approach to sustainability, as well as adjustment to environmental factors. Focusing on comfort and the general wellbeing of the resident, energy saving and environmental protection, the concept of Active House advances the synthesis of bioclimatic principles, architectural design and sustainable construction. The Active House concept is based on principles which have an evolutionary character, and the goal is to support and guide research initiatives which contribute to the constant improvement of quality in the realization of active principles. This leads to intensified cooperation concerning design on all technological levels during the entire process of building a house.

Establishing the Active House concept consists of 3 steps. The first step is to adopt a group of principles upon which the Active House concept is based. The second step highlights the importance of a holistic approach towards the active principles in the context of building a house, as an architectural and construction product. The holistic approach aims to unite all phases in a single and indivisible process, from conception, to construction, to utilization, through the influence of context, biodiversity, local culture and traditions. During this phase, a design method is developed which with the employment of suitable technological solutions can ensure an optimal performance level of the family home defined by (national) guidelines and technical requirements. The third step involves the guidelines and specifications which try to find an answer to all the three central questions faced by the construction industry: occupant comfort, energy saving and improving the environment.

\subsection{Key principles}

Comfort, as the first problem of Active House, is the need to ensure healthy and comfortable living. This problem is solved by designing a space which provides plenty of daylight and fresh air, as well as the use of materials which have a neutral influence on comfort and improve thermal comfort inside the house. Concerning comfort, the first principle is based on thermal conditions which ensure health and a sense of wellbeing. The second principle is based on good air quality, adequate conditions relating to thermal comfort, an attractive view from the house, and suitable visual and acoustic comfort. The third principle is based on indoor climate control easily manageable by the occupants, and encouraging environmentally responsible behavior among occupants. 
Energy saving as the next problem is an imperative among the active principles for realizing positive energy balance in the house. In the design phase it is important to provide conditions ensuring that the major portion of energy needs are met from renewable sources integrated within the house or even nearby sustainable sources integrated in the energy network. Concerning energy, the first principle is based on devising an energy efficient system which is simple to use. The second principle is based on designing the house which realizes to the full standards of energy efficiency defined in national or international strategies. The third principle is related to the utilization of various types of sustainable and renewable energy sources, which are integrated into the house through architectural design.

Protecting and improving the environment as the third problem is based on the fact that the environment must not be harmed by negative effects of house usage. By examining the condition of natural resources, their limits and potential for consumption, and by analyzing all the effects which the house may have on the environment through its lifecycle, the Active House strives to create positive interaction with its environment. Concerning the environment, the first principle is based on minimum negative effects on the environment and cultural resources. The second principle is related to designing a house which does not cause harm to the environment. The third principle is related to construction with materials which can be used again or recycled.

\subsection{The concept of energy self-sufficiency}

Over the previous decades, contemporary strategies for designing new housing models looking to provide more comfort to the occupants, with drastically reduced energy needs, have been studied through the passive house concept. Active houses keep up with the design and technology of passive houses, increase their sustainability, while staying focused on producing their own energy. Unlike the passive house which tries to save energy through maximum insulation from external factors, the active house strives to utilize certain external factors as sustainable energy sources, thereby reducing dependence on the primary energy network. Compared to net zero homes, Active Houses create so called 'positive' energy which can be fed back into the network. In fact the Active House produces energy for comfortable living. It is not a passive observer of environmental conditions, rather it actively participates in the environment, creating a unique symbiosis between the manmade and the natural, and has the potential to create its own energy supply. It is precisely this positive energy which keeps the entire system sustainable. The active principle predicts the possibility of improvements and constant additions to the capacities of technological solutions depending on the needs of the occupants (solar and hydro energy and the potential of climatic conditions is used...).

\subsection{Standards}

Standards recommended by the Active House concept concerning energy saving and sustainability, are most frequently based on the use of integrated solar panels, biomass, photovoltaic cells, wind energy, systems for storing and using atmospheric water, modular design, optimal size, flexible space, quick assembly and construction. Besides the aforementioned technical - technological solutions, preventing heat loss, are mainly related to heat loss that occurs through construction and thermal bridges. For this purpose special attention is paid to the choice and manner of installing thermal insulation, under 
floor heating based on sustainable systems, good quality joinery and hardware, use of glass with low thermal conductivity coefficient, external shading of glass surfaces which protects it from too much heat and internal shading of glass surfaces to prevent a drop in indoor temperature.

Energy efficiency requirements pertaining to individual renewable energy sources should be in accordance with national laws. As an alternative to national laws, standards of the EU Directive on the use of renewable energy sources (Directive 2009/28/EC, 2009) can be followed.

\subsection{Architectural solution}

The method in which the aforementioned nine principles integrate the architectural concept of the house depends on the conditions of the context and program, which become tools for authentic and unique architectural expression (see Fig. 1). The capacity of the contemporary tools of architectural design lies in the large number of possibilities for articulating demands for a comfortable, flexible and aesthetically pleasing ambience, on one hand, and technical-technological requirements on the other hand. Precisely this holistic approach represents the active potential of an architectural concept in which the house is seen as a sustainable mechanism/organism. It is possible to broaden the understanding of context and to interpret it through the subject of recycling and prefabrication brought to a level which would allow autonomy and authenticity in the process of architectural design and construction. Every climatic and cultural context carries specifications connected to the tradition of construction, which must be analyzed and their potential established with respect to realizing the goals of active principles.

Leading countries in the promotion and implementation of the principles of Active House are in the Nordic region, where special attention is paid to preserving and improving ideas embodying the simplicity of Nordic architectural expression, a harmonic relationship with the environment and sustainability. In Denmark worldFLEXhome by Nordisk Staal is producing a house created by the Danish architectural firm Arcgency in 2012, which is intended for Chinese market. It demonstrates the value and universality of the Active House concept concerning all three basic problems (Nordic Fund, 2012). The construction system is modular which makes use of shipping containers adapted to resist seismic and climatic conditions of the surroundings. The advantages of using this system can be seen in the short period of time required for construction, easy disassembly and transportation to a different location. Building materials are prefabricated, and the house is designed so that it allows serial production of high quality and distribution through standard shipping containers which makes it very competitive. The system allows for a lot of flexibility with respect to the capacity and personalization of the house. The architectural concept is based on Nordic values, which prefer simplicity of expression, flexible spaces, good natural lighting, and the use of healthy materials which provide warmth and age well.

\subsection{Establishing levels of realization of 'active' principles}

Success in the active integration of solutions for the three key problems of comfort, energy and environmental protection during designing, building and using the architectural product is described by the so called 'radar' of the Active House (The Active House Alliance, 2013). It shows to which degree the capacity of the solution has 
been realized at every level of the problem, and can display the precise degree to which the goals of the 'active' principles have been achieved. Realized capacities are divided into four levels, where 1 represents the maximum and 4 the minimum level of capacity realization in all three key principles.

Possible levels of capacity realization of the Active House include three goals which are to be met through nine principles, with recommendations concerning the lowest standards for each one. As long as levels of realized standards are higher or equal to recommended lowest standards, the house can be characterized as Active, within the framework of 'active' capacities which it has realized. The Active House radar is a tool which shows the manner in which all standards of the principles within the framework of resolving each problem depend on each other. It is possible to apply it to newly designed houses as well as houses which have been reconstructed. When a house is inhabited, the radar can be useful in monitoring and improving housing conditions. As a means of communication, it clearly demonstrates the significance and importance of taking into account all nine principles in order to achieve maximum capacity realization of the 'active' principle.
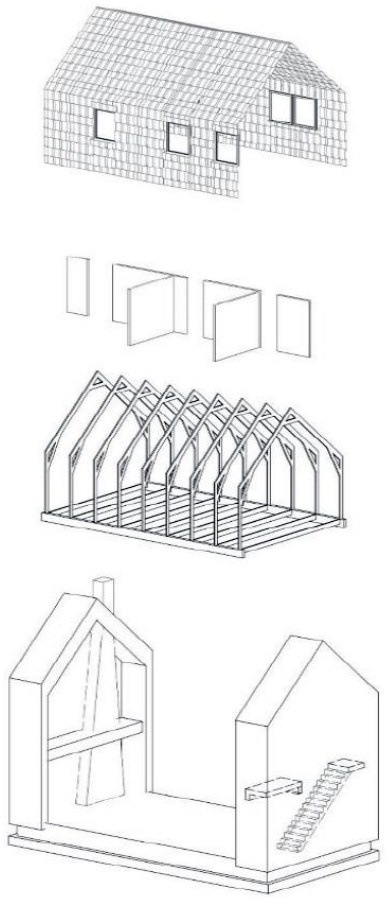
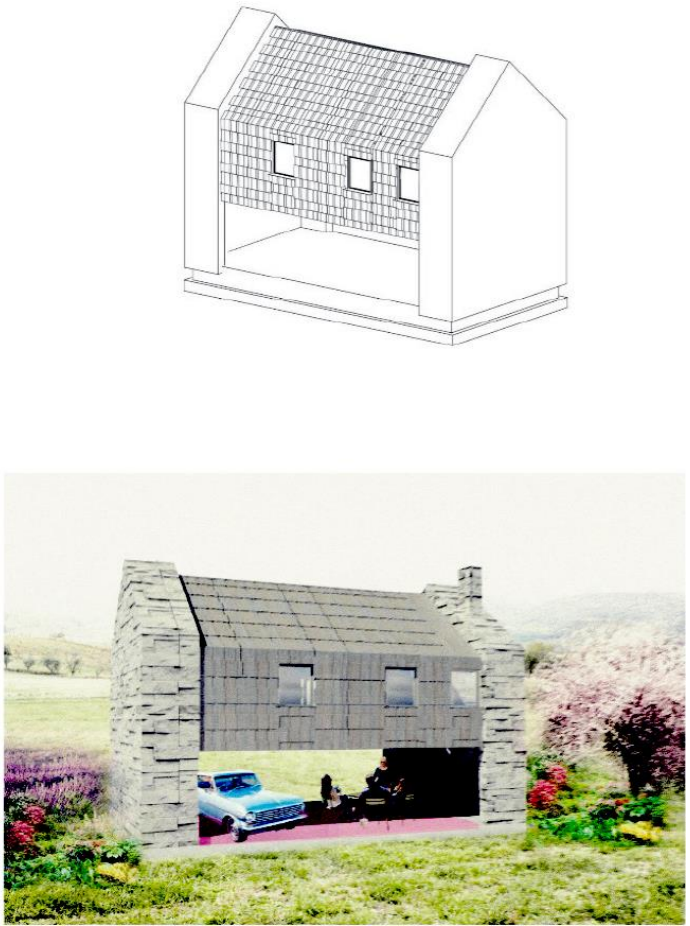

Fig. 1 Design solution for small family homes produced within the framework of the Active House Workshop, student-designers: Anđela Nikolić, Ana Obradović and Ana Popović (source: Faculty of Architecture Belgrade) 


\section{WORKSHOP 'ACTIVE HOUSE'}

Principles upon which the idea of the active house is based were formulated as a starting point for work within the framework of the design workshop 'Active House'. The workshop was held as part of a wider initiative by students titled 'New Housing Models for Flood Affected Population' at the University of Belgrade - Faculty of Architecture, at the beginning of June, 2014. The campaign was organized to offer help to affected communities and to provide assistance in efforts to repair and rebuild buildings in Serbia, which were hit by severe flooding (Arhitektonski fakultet u Beogradu, 2014). The general student initiative to help those affected by floods was supported by the academic staff at the Faculty of Architecture, and seven workshops were organized in which over 100 highly motivated students and 20 teachers took part.

Some 30 second to fourth year students participated in the Active House Workshop. With the cooperation of a few young architects and doctoral students at the Faculty of Architecture, the Active House Workshop worked on design solution projects for a small family home, with an area of $100 \mathrm{~m}^{2}$, which would be suitable to the standards of active house principles, and also possible to construct in emergencies, as quickly and inexpensively as possible, using local materials and resources (see Fig. 2). Such typological, spatiomorphological and technological requirements guided research towards the possibility of perfecting the existing model of prefabricated homes manufactured in Serbia, related to issues of identity, comfort, flexibility, energy consumption and rational building.

\subsection{The family home in May Floods}

Bearing in mind that the family home is the basic building unit of the overall built environment, and not only residential buildings, in Serbia, and that according to initial estimates the number of destroyed homes was over 2,500, it was only logical to use the family home as the object of research in a typological context. The initial estimates were later revised, reducing the number of completely destroyed homes. According to information presented by Serbian government Ministry of Construction, Transport and Infrastructure at the one day expert meeting 'New housing models for flood affected populations', (which preceded the student workshop), from 800 to 1,200 homes were destroyed in 24 municipalities in Serbia which were hit by floods. It was stressed that new homes should be constructed by the autumn of 2014, which further emphasized the need for quick construction. Data on the age and general condition of the destroyed or damaged buildings were not accessible. According to a rough estimate by workshop participants, relying on media reports, including social networks information, family homes destroyed comprised severely damaged homes, old homes, homes built using unsound construction techniques, or homes located in areas near watercourses and prone to landslides. It was possible to repair the majority of family homes damaged in the floods, and according to final estimates made at the beginning of July the number of completely destroyed homes stood at 484, the number of homes with 'partial structural damage' was 1041 , and as many as 14838 homes were 'temporarily flooded'. Furthermore, the size of more than half of the completely destroyed or structurally damaged homes were less than $80 \mathrm{~m} 2$ (Kancelarija za obnovu, 2014). 


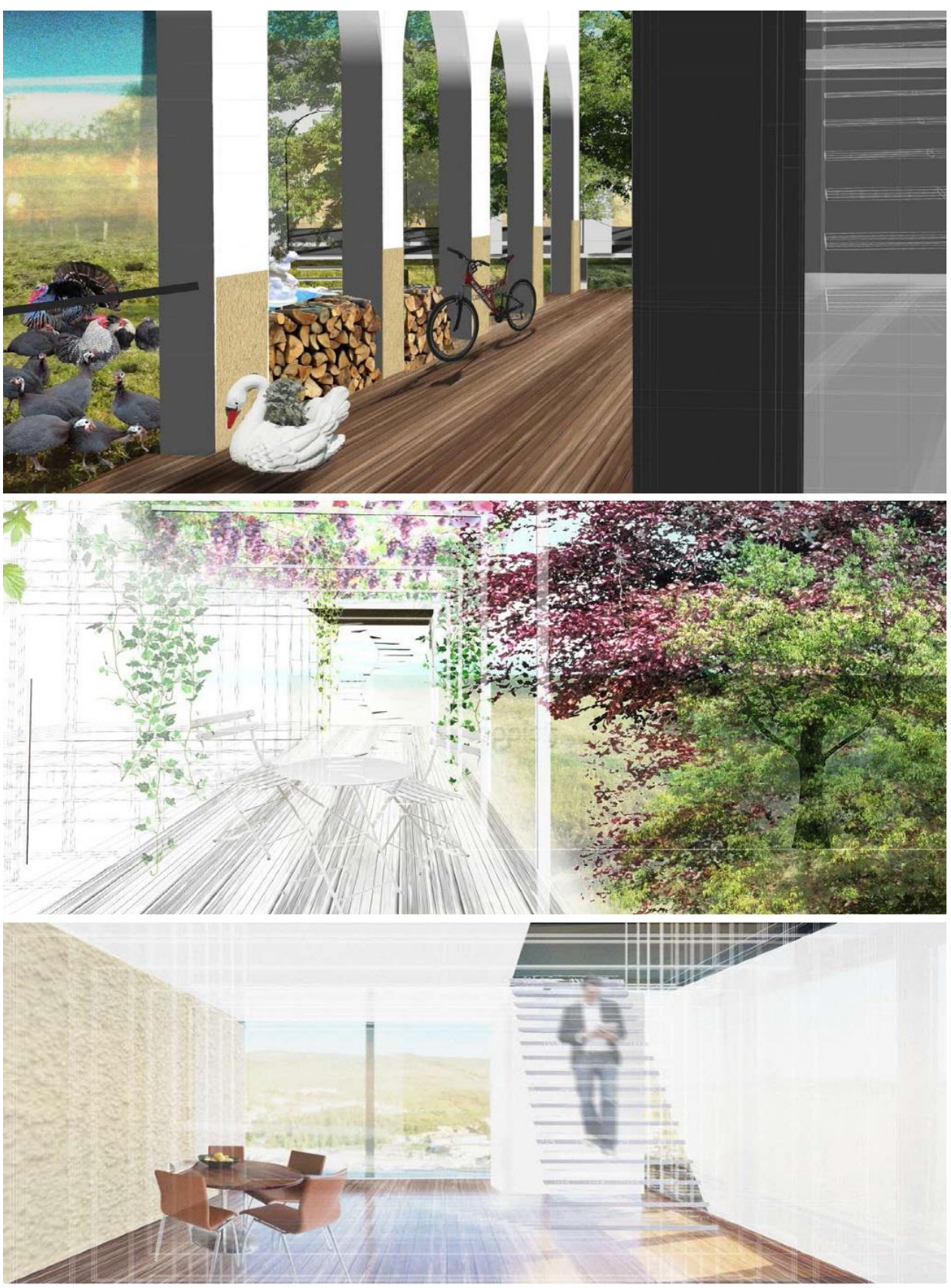

Fig. 2 Design solutions for small family homes created in the Active House Workshop, student-designers: Kristina Petković, Jelena Peljević, Maja Morošan, Janja Franeta (source: Faculty of Architecture Belgrade) 
On the other hand, when considering the data from the 2011. census in Serbia (Serbian Statistics Office, 2013), in the section pertaining to the number of homes built, the number of 'residential buildings with one home' stands at $60 \%$ of the overall number of residential buildings in all of Serbia, which essentially means that of the overall number of individual buildings intended for habitation at least two thirds are individual family homes, although some estimates put this figure as high as $87 \%$ of the total number of residential buildings (Jovanović-Popović, 2012). According to census data, on a regional level, the so called 'one home residential buildings' make up 75\% of the overall residential buildings in the areas of Vojvodina, Šumadija and Western Serbia and Southern and Eastern Serbia, an estimate which probably reflects the reality on ground most accurately (Zavod za statistiku, 2013).

In specific numbers, these are some 2,000,000 family homes. From this number around $12 \%$ of homes were built in the period prior to 1945 (mostly in Vojvodina), approximately $40 \%$ during the period from 40 s to 80 s, and a little less than $50 \%$ in the period from 1980 to date. These data throw some light on the official estimate which states that catastrophic floods damaged only some 500 family homes. When data from the Atlas of Family Homes are included stating that it is estimated that $83 \%$ of the total number of family homes do not have any kind of additional thermal insulation, and where the insulation has been added it was not done up to regulated standard, it can be concluded that the construction of residential buildings took place spontaneously, frequently without adequate planning documents and without planning permission. The majority of family homes in Serbia, and most certainly those which were destroyed or severely damaged in floods, were not only constructed without regard to energy regulations, which is a serious and complex problem, they were certainly not built to be resistant to flooding. In this sense, the task of the workshop could be described as designing an active house, potentially floodproof, built within a prefabricated system in domestic conditions.

\subsection{Active house principles and architecture of necessity}

Even though the selected active house principles are applicable to other housing typologies, particularly those in which socially and physically sensitive groups spend a large amount of time (such as child daycare centers and schools), these buildings were not the subject of the workshop primarily because of the aforementioned acute problem concerning residential buildings, during which the workshop was held. While working with students three basic groups of values were highlighted, which in essence form the concept of Active House: (1) comfort, (2) economy and (3) positive influence on environment. When the comfort of the population is presented as a priority, on the same level as the necessity of saving energy, furthermore when it is insisted upon that every new house should have a positive influence on the environment, then clearly and without any dilemma all the neuralgic points of the project are stabilized, even in situations where housing has to be provided in an emergency, as was the situation during the May floods. The position taken was that no emergency can be so hasty, that clear and purposeful action cannot be taken within the framework of these three groups of values, since they are unequivocally related to the personal wellbeing of those affected, and to the future recovery of society and the country as a whole. 


\subsubsection{Comfort}

The principle, according to which lighting and visual comfort of the population is specified as a priority, is strategically important, especially when it is taken into account that usually in critical situations priority is given to other dramatic problems, which are related to bare survival. In the process of preparing design priorities it is an ethical decision that every, even the smallest and most urgent project must be examined for the quantity of daylight, control of sunlight and positioned for the best views (see Fig. 3). Unlike passive houses, which owe their emergence to the idea of the cave, active houses are open to the environment, which make their efficiency a sensitive question concerning energy, but this is also the reason why they are significantly healthier for the occupants. Apart from views, lighting and sunlight, the amount of indoor air also plays an important role, to the extent, that it is insisted upon that the volume of indoor air should not remain at a single standardized limit. This condition influenced the decision that in all projects designed in the workshop, that the flat ceiling slab should be excluded as a construction element, which also proved to be a good decision in terms of reducing building costs. Conditions for good natural ventilation, or natural temperature control, presumed the formation of openings on all sides of the shell of the basic volume of the house, including the slanted roof.

\subsubsection{Energy saving}

The design decision that making the house volume compact is a good starting position and it is the first and very important step towards energy saving. Technically, it is assumed that there is thermal insulation for the floor, walls and the roof, according to national regulations. Furthermore, the size and type of openings which adhere to the group of values related to lighting and visual comfort are formulated through the strategy $50-50$, which is to say that the overall surface of the external membrane should be distributed as uniformly as possible over glass and the total surface of walls and roof. Treating the glass surfaces with additional internal and external blinds or shading is included in the phase of the design resolution, and it would be carried out during later phases of the project. Meanwhile, from the time of holding the workshop a certain number of technical expert studies appeared which deal with this problem, with the general conclusion that because of a need for additional energy saving it is enough to envisage adequate additional internal/external blinds or shading (Holzer \& Foldbjerg, 2014), an assumption also made during the workshop. The manner in which additional shading would be controlled is a separate issue, and basically we are dealing with the technological possibility of computer controlling the central house system which would take care of the indoor climate. From a technical point of view, for small houses built on an area of around $100 \mathrm{~m} 2$, which were the theme of the workshop, mechanical control would not be necessary because of easy manual control.

The condition of minimal energy consumption is based on the idea that the level of indoor heating should be in accordance with the kind of physical activity taking place within. This means that it should be cooler or warmer where necessary, cooler in areas for sleeping, warmer in sitting rooms and warmest for bathing, etc... In our domestic circumstances of family housing, because of the high prices of energy, only certain areas are heated. These are bad conditions for comfort, the difference between areas that are heated and those that are not are huge, so that thermal accumulation cannot play its 
mediatory role. How to deal with this problem? As with blinds, the simplest way would be to regulate varying levels of temperature for each area, connected to the purpose for which they are used, which in these circumstances would mean manual control of heating devices separately in each area.

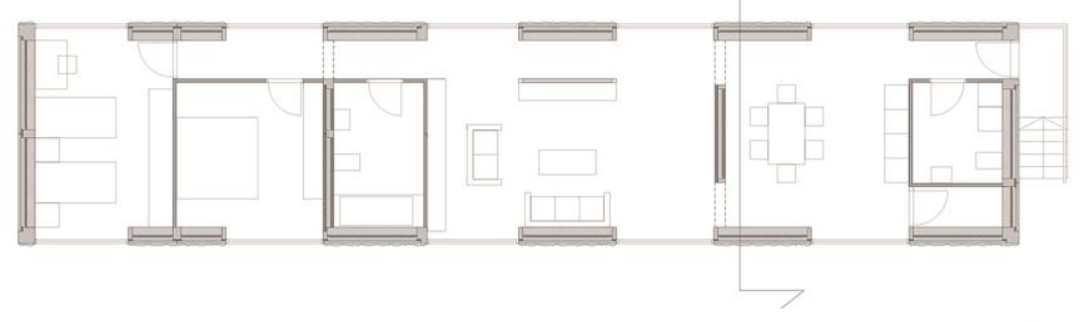

Bruto površina: $133 \mathrm{~m}^{2}$
Neto površina: $113 \mathrm{~m}^{2}$

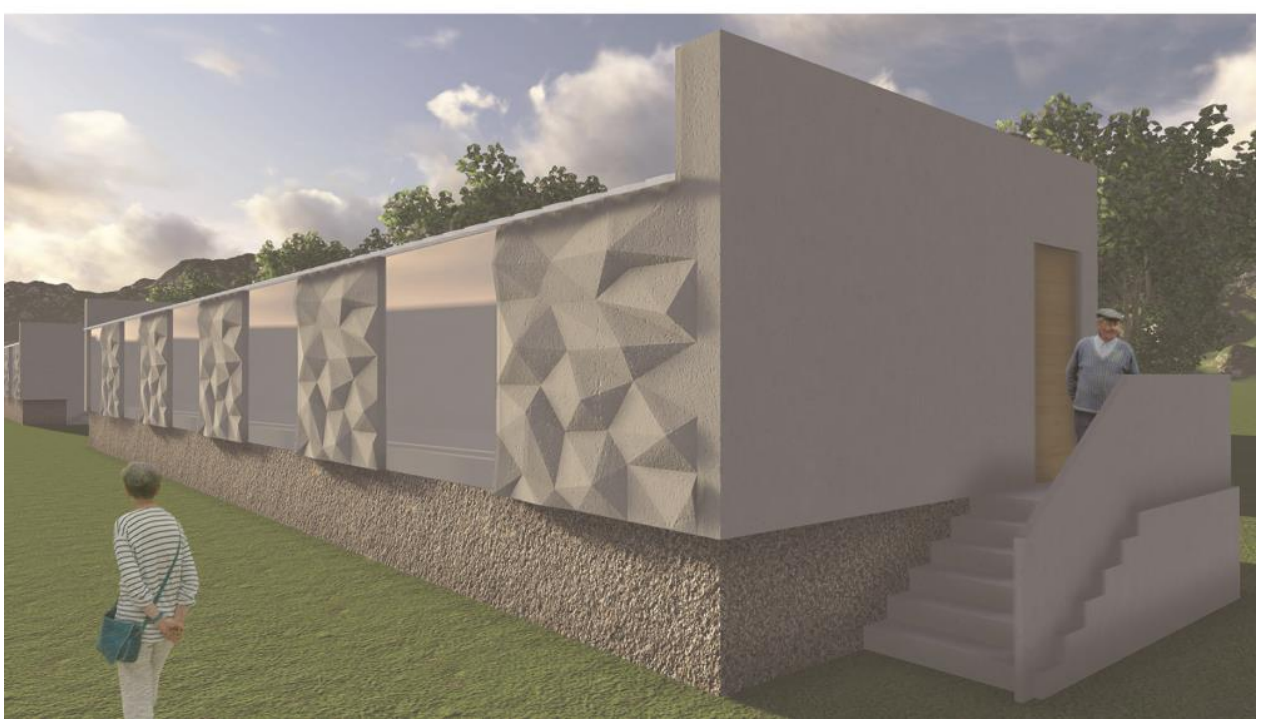

Fig. 3 Design solutions for small family homes produced in the Active House Workshop, student-designers: Uroš Vuković, Petar Veselinović, Borko Marković (source: Faculty of Architecture Belgrade)

When it comes to including additional energy sources, in local conditions this would primarily mean integrating solar panels in the overall design of the house. Considering that the number of daylight hours in Serbia is 1500 - 2200 per annum, it is completely unclear why solar energy is always left out of consideration when it comes to deciding upon standards which must be followed, above all, while building family homes (Lazarevic, 2013). Family homes in Serbia, equipped with photovoltaic solar accumulators and solar powered boilers for heating water would most probably produce more than the necessary amount of energy which is consumed during favorable weather, which leads us to the question of the possibility of including additional small producers in the energy 
network. The potential of 2,000,000 family homes throughout Serbia, which could produce enough energy for their needs, as well as for others remains to be considered, and giving independent energy producer status to small consumers/producers will be a huge and important challenge for any society in the times to come.

\subsubsection{Positive influence on environment}

While implementing regulations connected to thermal comfort, the necessity of energy saving is related not only to energy efficiency understood as the installation of enough thermal insulation and using windows with thermal insulation, but also to the kinds of materials which are used, the sustainability of technology which is used in their manufacturing, their real life effect on the life and health of people when they are utilized, as well as their life expectancy. Artificial, polymer based materials are an illogical choice when used in combination with brick and clay products, of which most of the residential buildings in Serbia are constructed. Work done in the Active House Workshop should also be seen as criticism of the construction industry which frequently promotes the use of materials whose manufacturing is part of the global oil and chemical industry. The question is whether waste of energy in badly insulated homes is a bigger problem than the installation of plastic materials which are almost completely non-biodegradable. Apart from recycled glass wool, and stone wool, natural insulation materials are still available in Serbia such as cane and hay, as traditionally used healthy materials, which also allow brick or clay walls to 'breathe'. Even though the use of plastic materials certainly has its standardized place in the construction industry, using only them cannot possibly be of benefit to the environment.

Low carbon emissions from the house when lived in, or minimization of the harmful influences of the house on its environment, is mainly related to heating systems and air pollution. Besides reducing the need to use heating, achieved by principally saving energy, modern wood stoves can be used which are capable of complete combustion and are in the category of heating systems which have a small impact on the environment, although not less than gas or oil stoves. When one takes into account production technology, accessibility and energy prices, the efficiency of stoves which burn wood or waste wood are an alternative, or even a basic and economic choice, as commented on The Tree Hugger Blog in 2011. Saving fresh water means storing and using atmospheric water for all purposes which do not require technically safe water, and using suitable home appliances, as well as choosing porous materials for flooring in yards and around the house, which make it easier for water to drain into the ground during storms when a large quantity of water gets collected, as stated in Conserve Water guide by US Environmental Protection Agency.

\subsection{Possibilities for realization}

From the material presented above, it is clear that houses which are to be built according to active principles are nominally more costly than the ones which are usually considered inexpensive, primarily because of the top quality materials used and the additional equipment. One of the ways to deal with this problem would be to use building materials which would otherwise be considered waste materials. For instance the Danish pilot project worldFLEXhome, was made of recycled shipping containers, which are available in plenty on the Chinese market. Prefabrication in Serbia has never played a big part in the construction of family homes, except in emergency situations when affected 
people had to be provided shelter quickly and efficiently. On the other hand, we are talking about a cultural context in which the problem of identity related to a 'prefabricated' house is difficult to accept and quite disliked. Similarly, considering that independent investment in construction should be more than in a semi or completely prefabricated build, it seemed that the active principle could primarily be realized precisely through this type of construction. The circumstances in which the workshop was held, independent investment was even impossible, and it was a separate issue to which degree individual environmental awareness should be developed so that quality is taken into account which would prove its value in the long term. At such times the enlightening role of the architecture professionals and the state as their exponent has an immense value.

\subsection{Educational experiment}

During the workshop students came up with nine design solutions including the Active House principles. The starting point in the design process was recognizing the potential for the 'active' principles in existing construction techniques, where the location of the material, working with the material and the time needed to deal with both issues had a crucial bearing upon design concepts. These solutions could serve a contemporary basis for perfecting existing models of prefab houses in Serbia, providing an answer to the problems of identity, comfort, flexibility, energy consumption, and also quick construction. On a general educational level, we are talking about the idea of the object of architecture which is initially given the basic life value, and which could gain a conceptual status close to a 'live' organism or, at least daily life. Unlike a situation where the status of the object of architecture is in the category of artifact (technological, artistic), standards of design procedures are transferred outside an one way context in which for the sake of design the theoretical or practical model of the object of work itself is seen as a passive thing. In an active context, the concept of work presumes roughness, intentional incompletion, even raw architectural solutions, which leave scope for external input from all categories of life.

The term 'active' appeared in architecture after the determination to make 'efficiency' a key for understanding the direction in which modern architecture should be heading. That which would be (enough) modern in today's architectural context, is related to a careful consideration of the conditions in which the architectural product would behave as an active element in the life of its occupants, and an active being in its environment, and an active agent of that which is currently referred to under the collective term 'climate change'. In short, this is another opportunity to broaden our understanding that every act, including the act of building, is a step towards the future, except for the one we desire and the one we will ordain for ourselves.

\section{CONCLUSION: INTERVENING CAPACITY OF ACTIVE HOUSE}

Accepting change as a possibility for development on a general level is difficult for any individual at any level, especially when it comes to the formation of the complex concept of home. Allowing for the development of an emotional relationship between the individual and their daily space, is the most sensitive task for an architect. However, it is precisely by meeting this very difficult demand, that we can find a way to ensure success for the housing model presented. 'Vulnerable' social groups exhibit various reactions to 
different approaches with which social institutions deal with their issues. Strict hierarchical models of intervention which work top-to-bottom, frequently face opposition, while the completely different bottom-up model where work is done in cooperation with local populations in all phases are more effective, from formulating the concept of a project to the realization of the goal. Awareness about changes in social mechanisms in crisis situations, introduces new premises in the design process for the architect. The quality which is expected from the architect is not classified in only spatial categories, rather also in the possibility of accepting and adopting this spatial framework through subjective and intimate daily routines of individuals and social groups.

In this inclusion of specific local factors in the design process (of the widest range: from cultural housing models to local materials and construction techniques) we look for the capacity to renew the creative potential of the discipline through limits which are imposed by emergencies with all their local and specific issues, which become new possibilities for the development of architectural concepts. The process of cooperation with the population represents yet another of the aforementioned limitations/new possibilities for the design process, since alterations in the subjective ideas of a better life for each member of a community requires gaining confidence not only in the spatial framework which is offered by architecture, but also in accepting the changes brought by the future.

In the widest possible social context of the third millennium, the need to seek architectural solutions which will contribute to resolving global humanitarian disasters is very obvious, became the crisis situations are frequently a result of the now long standing and problematic relationship between man and the environment.

The need to think about problems posed by modern living conditions through the 'active' category in an architectural context is visible in the way modern architectural paradigms are being developed to a redefining of the very basic tenets of the discipline oriented towards a systemic understanding of nature and natural, so that the relationship between the built and the natural in architecture is formulated as a means to investigating new principles for the sustainability of natural resources.

\section{REFERENCES}

1. „Brundtland Report”. UN Documents, Gathering a Body of Global Agreements, 1987. http://www.undocuments.net/k-002988.htm [10.04.2015.]

2. "Directive 2009/28/EC of the European Parliament and of the Council of 23 April 2009", 2009. http://eur-lex.europa.eu/legal-content/en/TXT/?uri=CELEX:32009L0028 [6.04.2015]

3. Nordic Fund for Innovation,,WORLDFLEXHOME House“, Nordic Built. At Nordic Fund for Innovation, $2012 \mathrm{http}: / / \mathrm{www}$. nordicinnovation.org/nordicbuilt/cases/case-category-9/wfh-house/ [30.04.2015.]

4. The Active House Alliance, ,Active House specifications for Residential Buildings“, 2nd edition, 2013. http://www.activehouse.info [30.04.2015.]

5. Univerzitet u Beogradu - Arhitektonski fakultet, "Novi modeli stanovanja za ugrožene u poplavama", 2014. http://www.arh.bg.ac.rs/2014/06/11/radionice-novi-modeli-stanovanja-za-ugrozene-u-poplavama/ [25.04.2015.]

6. Kancelarija za pomoć i obnovu poplavljenih područja vlade Republike Srbije, "Poplave u Srbiji 2014", Beograd, 2014, pp 58. http://www.obnova.gov.rs/uploads/useruploads/Documents/Izvestaj-o-procenipotreba-za-oporavak-i-obnovu-posledica-poplava.pdf [6.04.2015]

7. Serbian Statistics Office, "2011 Population and Housing Census", Belgrade: Serbian Statistics Office, 2013

8. M. Jovanović-Popović, et al., Atlas of Family Housing in Serbia, Belgrade: Belgrade University Faculty of Architecture, 2012, pp 19

9. Republički zavod za statistiku, Popis stanovništva, domaćinstava i stanova 2011. u Republici Srbiji, Beograd: Republički zavod za statistiku, 2013, pp 21 
10. P. Holzer \& P. Foldbjerg, "Control of Indoor Climate Systems in Active Houses", World Sustainable Buildings 14 Barcelona Proceedings, 2014, pp 9-15.

11. B. Lazarevic, B. Lepotic Kovacevic, "Construction of Plants and Electricity Generation in Solar Power Plants in the Republic of Serbia - Guide for Investors", First Edition Belgrade: Serbian Ministry of Energy and Mining, 2013

\section{AKTIVNA KUĆA: SAVREMENI STAMBENI MODEL ZA UGROŽENE U POPLAVAMA}

Snaga arhitektonskih znanja u borbi za bolju budućnost pokazuje se kroz stav da dobar projekat, odnosno kvalitetno arhitektonsko rešenje, ne pripada samo privilegovanima kao nadogradnja elementarnih uslova, već upravo obrnuto, da ono nastaje tek u okvirima nužnosti.

Cilj zdravstvenog $i$ emotivnog blagostanja, ukršten sa dugoročnom težnjom da se negativan uticaj građenog okruženja umanji $i$ preinači u pozitivan doprinos prirodnoj sredini, spaja $i$ unapređuje bioklimatske principe, arhitektonsko projektovanje $i$ održivost gradnje $u$ koncepciji Aktivne kuće. Ideja o Aktivnoj kući sažima obezbeđivanje komfora i opšte dobrobiti korisnika sa energetskom efikasnosti i zaštitom životne sredine.

Radionica Aktivna kuća održana je, kao deo šire akcije studenata Novi modeli stanovanja za ugrožene u poplavama, na Arhitektonskom fakultetu Univerziteta u Beogradu, u svrhu pružanja pomoći ugroženoj društvenoj zajednici $i$ doprinosa sanaciji objekata na području Srbije, pogođenom ekstremnim poplavama u maju mesecu 2014. Tokom rada u ovoj radionici studenti su proizveli devet idejnih rěsenja malih porodičnih kuća gde su prepoznali principe Aktivne kuće u postojećim tehnikama gradnje. Na opštoj obrazovnoj ravni, reč je o proširenju zamisli predmeta arhitekture, tako što mu se inicijalno dodeljuje osnovna životna vrednost, čime bi mogao da zadobije koncepcijski status blizak živom organizmu, ili bar svakodnevnom životu.

Potreba da se o problemima savremenih uslova života razmišlja kroz kategoriju "aktivnog" u arhitektonskom kontekstu manifestuje se kroz novo razumevanje prirode koje omogućava da se zamene pasivni modeli arhitektonskog saniranja posledica aktivnim modelima projektovanja sadejstva sa okruženjem.

Ključne reči: Aktivna kuća, stambeni model, udobnost, arhitektonsko projektovanje, uticaj na okruženje, majske poplave. 